\title{
Bilingualism in Colombia Higher Education ${ }^{1}$
}

\section{Bilingüismo en Educación Superior en Colombia}

\author{
Sandra Liliana Martínez Rincón ${ }^{2}$ \\ Universidad de Boyacá \\ lilimartinez777@hotmail.com
}

Received: April 6, 2016

Accepted: June 27, 2016

How to cite this article (APA, $\mathbf{6}^{\text {th }}$ ed.): Martínez, S. (2016). Bilingualism in Colombia Higher Education. Enletawa Journal, 9 (2), 91-108.

\begin{abstract}
This theme review describes aspects related to bilingualism and its incidence in higher education. Specifically, the author shows a brief overview of what bilingualism means; what the National Bilingual Program started in 2004 and its evolution into Colombia, very well for 2015 entail in terms of their impact on both teaching and learning; and the importance for the Ministry to modify certain aspects regarding bilingualism in education in our country.

The paper also includes some studies and theories which support the author's statements as well as the introduction of some current events at a private university in Sogamoso, Colombia, which are directly related to the matter of bilingualism. Finally, the author presents some conclusions from the present paper.
\end{abstract}

Key words: Bilingualism, Colombian Higher Education, National English Program.

1 This theme review, emerged from an essay made for the Seminar on Sociolinguistics seen in the third semester of the Master's in Language Teaching.

2 Holds a B.A. in Foreign Languages. She is an Educational Management specialist and a M.A. student in Language Teaching from Universidad Pedagógica y Tecnológica de Colombia. She is currently working as an English professor at Universidad de Boyacá. Moreover, she has focused her research work on the higher education problems looking for the teaching and learning aspects improvement. 


\section{Resumen}

Este artículo de revisión temática describe aspectos relacionados con el bilingüismo y su incidencia en la educación superior. Específicamente, el autor muestra un breve retrato acerca del significado del bilingüismo; lo que conlleva el Plan Nacional de Bilingüismo iniciado en el año 2004 y modificado en el 2015, no solo relacionado con el aprendizaje sino además con la enseñanza; y la importancia que tiene para el Ministerio modificar ciertos aspectos concernientes al bilingüismo en nuestro país.

El artículo también incluye algunos estudios y teorías que apoyan las declaraciones del autor, así como la introducción de eventos actuales de una universidad privada en Sogamoso, Colombia, los cuales están directamente relacionados con el bilingüismo. Finalmente, el autor presenta algunas conclusiones del presente artículo.

Palabras clave: Bilingüismo, Educación superior colombiana, Programa Nacional de inglés. 


\section{Introduction}

Bilingualism has become a very popular word today in Colombia. The importance of knowing English and/ or other foreign language(s) is evident, considering the different aspects that demonstrate how becoming bilingual is really beneficial for most people. The person who is fluent in more than one language has more possibilities to obtain a scholarship in foreign countries, to get a better job, to access a wider range of opportunities in life. Colombia nowadays is much more open to the rest of the world in business, education, and tourism, in part because of the possibilities afforded by the different entities that try to offer bilingual education. There are several private institutions where English has the same relevance or even more than other subjects taught. One example of this is a private university in Sogamoso, where students have six hours of English and two teachers per level, and they are also given useful tools to strengthen their different abilities and master their language skills. However, according to my personal experience, this is not observed in the first level of English where students have a low level in this language. Their low competency level illustrates how results from primary and secondary education have an influence on students' performance in higher education.

When talking about bilingualism, it is relevant to discuss why it is useful for a person's life, as has been defined by different authors and from my point of view. According to Asha (2004), bilingualism is defined as the use by an individual of at least two languages. This general definition reflects what the Colombian government has wanted to achieve since 2004; in Colombia, Spanish is our native language, but the objective for the government was to have citizens capable of communicating in English in order to be able to include the country in the processes of universal communication within the global economy and for intercultural exchange through the adoption of internationally comparable standards (MEN, 2006).

The standards adopted are based on the Common European Framework of Reference for Languages (CEFR). The decision to adopt these standards was based on the government claims that adopting this foreign framework will allow Colombia to improve and advance in other contexts. Ayala and Álvarez (2005, p.12) address this issue as follows:

Because Colombian standards for foreign language teaching are barely structured, attention has been given to foreign models. In general, standards have been obtained by importing the ones that were developed in other places under different circumstances and contexts. Although those standards are valid and reliable for foreign academic communities, it does not mean that they would fit the particularities of our institutions, language learners and so on. 
The key here is to understand how these adopted standards fit in our country and how student outcomes influence English learning at university level.

This paper intends to discuss how bilingualism is being implemented in higher education, taking as point of departure the education in the schools, the challenges regarding this implementation, and the roles teachers and students have in this process; I describe these aspects from different authors' opinions, academic studies, and my personal experience. At the same time, it describes the standards that guide the bilingualism program in our country as an important issue to be analyzed and considered due to its implications on higher education.

\section{Literature Review}

\section{Bilingualism.}

Bilingualism has a lot of definitions, often in accordance to the focus people give to it. Linguists and psychologists usually define bilingualism in terms of the way people control both their languages and of bilingual language competence (Skutnabb-Kangas 1984). Bloomfield (1933, p.56) quoted the classical definition of bilingualism in Skutnabb-Kangas: "native-like control of two or more languages" (1981, p. 85). This means that a person should be able to use two or more languages as well as a native speaker. Braun (1937, p.115) cited in Skutnabb-Kangas (1981) states that a person should be able to have a complete command over two or more languages. The researcher agrees with Skutnabb-Kangas considering that bilingualism describes the ability people have to understand and make themselves understood in two different languages. Bilingual proficiency entails being able to effectively communicate our thoughts, ideas, feelings, points of view and be part of a community in both languages.

Being bilingual results from different circumstances. One of them is the opportunity a person has if s/he is a child growing up in a place or family where a second language is used or needed for the accomplishment of different tasks. Another reason is geographical migration due to the political, social or economic situation in someone's home country, as well as cultural and educational factors. This often leads to intermarriage, marriage between two immigrants from different countries or marriage between an immigrant and a native person (Grosjean, 1982), and reinforces the need for bilingual proficiency.

Two facts about language acquisition are consistently supported in research. First, most everyone can learn one or several languages; and second, the success of this learning depends on the real need or wish to use the new language(s) in authentic communication (Snow, 2007). According to this assertion, nearly any person has the possibility to learn a language, but it depends on the 
degree of necessity and potential for use in real life. The problem in Colombia is that our sociolinguistic context is mostly monolingual in Spanish. This means that we do not need to use English to function in society. As De Mejía (2011) states, bilingualism should be seen as an opportunity to understand, respect, and protect the cultural and linguistic diversity of the world, and not as a way to extol a particular language.

English is seen mainly as a means to increased competitiveness and internationalization in Colombia, and this is reflected in the ethos of the National Bilingualism Program which, in spite of its title, only refers to one type of bilingualism: English-Spanish. It also does not take into account the many other languages spoken in the country. In fact, Valencia Giraldo (2005) has observed that:

As a result of globalization and widespread use of English worldwide, the term 'bilingüismo' [bilingualism] has acquired a different meaning in the Colombian context. It is used by many (...) to refer almost exclusively to Spanish/English bilingualism (...) This focus on Spanish/ English bilingualism now predominates, and the other dimensions of multilingualism and cultural difference in Colombia are often ignored ( $p .1)$.

\section{Private university context.}

In the case of this specific private university in Sogamoso, bilingualism is one of the most important aspects to develop because the academic vision states that students will reach the A2 level according to the standards of the Common European Framework of Reference for Languages (CEFR). Students come from different schools, especially from public institutions. They only have two levels of English, with a third one that is optional for them. At the end of their studies, students must take an English proficiency test on which they should demonstrate they have an A2 level in order to graduate. The issue here is that most of the students fail this test, and some have to take it several times to succeed. This issue needs to be analyzed in order to find why this is happening and how bilingualism is being implemented in this university by all parties involved.

\section{National Bilingual Program and its influence in higher education.}

In 2004, the Colombian government outlined its plan for bilingualism in Colombia, which evolved in 2015 to a program called Colombia, Very Well, the mandate for which extends up to 2025. It is the answer to the challenge imposed by competitiveness and globalization, to improve educational quality by means of developing English language competencies in children and young people throughout the country. This program focuses on three fundamental components to be developed over ten years: the first one is strategies for teacher training 
and design of pedagogical materials, followed by the enhancement of quality, accompaniment and funding for higher education, and finally by coordination with the private sector.

The National Bilingualism Program was created with the objective that teachers and students attain certain English levels established by the Common European Framework of Reference (CEFR). The reasons given for adopting the CEFR were that it was the result of ten years of research and that it provided a common language to establish foreign language performance levels throughout the Colombian educational system, particularly in relation to international standards. The Ministry of National Education explains that "the adoption of a common referent with other countries will allow Colombia to examine advances in relation to other nations and introduce international parameters at local level" (MEN, 2006).

The colonial ideology in which Europe was presented as the paradigm of what the world should be like (Pennycook, 1998; Ruiseco and Slunecko, 2006) was so pervasive that even today, in some fields like education, we adopt Eurocentric models guided by the idea that they know better (Ayala and Álvarez, 2005). The adoption of not only the CEFR but also of the instructional methodologies, teaching training programs, materials and tests perpetuates the inequity between local knowledge and the knowledge of the former colonial powers (González, 2007).

This program has raised several criticisms by different academics from some of the leading universities in the country, some of whom have carried out studies related to bilingualism in our country and with direct actors such as teachers and directors. Some of these academics are: Fandiño, Ramos and Bermúdez (2016), who address in their article the necessity of teacher training to transform and innovate foreign language teaching; Cárdenas, Chávez and Hernández (2015), who implemented the National Bilingualism Program in Cali and uncovered the real situation from the teachers, students, parents, and administrative staff; González (2015), who criticizes the policies that promote bilingualism in Latin America; Usma (2015), whose studyhighlights the unpredictable nature of policymaking processes, that even when transnational organizations act as policy lenders and guarantors of success and credibility, the policy mandates are often accompanied by standards, tests, frameworks, and timelines that do not necessarily respond to the local needs and expectations of local educational actors and communities. These criticisms have shown the positive and negative impacts which the National Bilingualism Program is having on the different Colombian institutions where it is being applied. 
One of the criticisms some researchers have made about the adoption of the CEFR is the nature of particular sociocultural conditions in the country. Cárdenas (2006) postulates that the reality established in the CEFR would have to be contrasted with the conditions of Colombian educational institutions, namely in terms of infrastructure, curriculum organization, use of foreign languages in the academic and cultural domains of the country, working hours and language teacher competency.

The aforementioned factors are relevant in terms of implementing a program based on other contexts and places. Does it make sense to apply some standards used in other countries totally different from Colombia and expect them to work and be successful here, as intended? National governments tend to adopt different rhetoric and models accepted by an imaginary "international community" or a concrete other which is evoked as a source of external authority (Usma, 2004).

In November, 2007, Cely, academic consultant to the National Bilingual Program at the Ministry of Education considered that the CEFR was the framework that could best guide some of the policies for English education in the country. She noted specifically that,

The Ministry found the CEFR to be a guiding document which is flexible, adaptable to our Colombian context, complete, sufficiently researched, used throughout the world in general and in the Latin American context in particular, which has finally been accepted as the referent for the Bilingual Program. (Cely, 2007, p. 12).

This statement shows that we are following foreign standards which have worked successfully in other places, but without taking into account our own needs and context. English is not a priority in many places in the country, particularly in remote rural areas and in areas with displaced populations due to the internal conflict. Therefore, in order to work effectively, application of the CEFR would need to be modified to fit the particularities of the Colombian context. In this case, the expectation that school students reach level B1 is unrealistic, based on historical evidence. The government should first analyze the context in which this program is going to be applied and then identify aspects to improve. In the private university in Sogamoso, the students are compelled to acquire an A2 level of English as a graduation requirement. This level is even lower than the level which students are supposed to acquire in schools, but based on my experience, students are entering higher education with a really rudimentary foundation in English.

Regarding the implementation of the bilingual program in specific geographical locations, there have been voices raised in support of a more inclusive vision. One of these is Cárdenas (2003) who has argued for the importance of including a more 
egalitarian viewpoint in relation to language policy. In a letter written in 2003 to Antanas Mockus, the Mayor of Bogotá at the time, in relation to the policy of Bogotá Bilingüe, she states:

A bilingual strategy would have to privilege, in equal conditions, the treatment given to the first, or the majority language of the population, as well as the language which is being promoted for academic or competitive goals. Even though there is an urgent need to be competent in English, the strategy that people have decided on for the city cannot be limited to two languages ( $p$. 154).

\section{Teachers' position.}

It is important to pay attention to the warning against exclusivity of one language of power and prestige. We need to look both outwards towards a globalized world as well as inwards to focus on local linguistic complexities. Another challenge is to know how the acquisition of a foreign language is contributing to relevant outcomes such as a more understanding and tolerant society. It is not only about paving the way to a better job or higher standard of living.

A further important point of dissent is the role of foreign agencies in the implementation of the official language and education policies governing the teaching and learning of English. The adoption of the CEFR as the point of reference for policies concerning the National Bilingual Program has meant that private agencies, in particular the British Council, have assumed a dominant role in many of these processes, even imposing British tests. At the same time, there is a development that has touched Colombian teachers, that of the arrival of foreign assistants at public schools. Sometimes these assistants are not English native speakers or teachers, but are simply people who speak this language. The author is not against the opportunity of teachers to have an assistant whose role is to help them and support their work, thus making it better for students; however, the government should give local teachers the chance to participate in this kind of program, taking into account the fact that there are many local teachers who have been abroad and can thus carry out the same tasks as the foreign assistants.

The author considers that the government must invest more money in courses and teacher training for English teachers as a means of improving teaching effectiveness. There are many English teachers who have graduated from excellent, recognized universities in Colombia; nonetheless, they are not paid well in the public school systems, where sometimes the government prefers to ask teachers of other subjects to teach English classes, regardless of whether they have the abilities and knowledge needed to help students acquire higher English proficiency levels.

According to Cárdenas (2006), there is also a tendency towards dependence on the results of examinations based on 
the CEFR in order to make decisions about students' foreign language proficiency, rather than considering additional indicators within the language learning process. Aspects such as the proficiency demonstrated across the different activities carried out in class during the school year as well as the students' overall communicative ability in a different language are not taken into account when determining if a student has a particular proficiency level in English. Another problematic aspect is that universities are forcing students to obtain certain level of English to graduate, without taking into account the low level they have from their schools nor the sometimes inadequate number levels of English available at the university. Regardless, at the private university in Sogamoso, for example, students still have to take a proficiency test at the end of their studies as graduation requirement.

One of the reasons given by the Ministry of National Education for adopting the framework in Colombia was the amount of research evidence available; but in fact, according to Hulstijn (2010), the CEFR is not based on empirical evidence taken from L2 learner data. Instead, its empirical base consists of judgments of language teachers and other experts with respect to the scaling of descriptors. This statement speaks to our national circumstance, in that the standards do not fit our context and educational needs, plus the imposed framework is not a result of in-depth research made in Colombia but rather in Europe. Analysis of foreign contexts was used to decide and plan to implement a program like this here.

Teachers are not given too much relevance when it comes to implementing government demands. The English teacher's role is considered quite mechanical (Guerrero and Quintero, 2005), and they are not usually thought of as intellectuals (Giroux, 1988) who can tackle critical issues within their classes nor challenge the status quo at all. However, many Colombian teachers of English have proved them wrong and have started to see their profession as much more than teaching empty structures (González, 2007; Vargas et al., 2008).

\section{Low English level from schools.}

When talking about the challenges facing bilingualism in higher education, it is necessary to describe what is happening in the schools regarding the English level the students have when graduating from high school and entering higher education.

There are some reasons why English proficiency is often at such a low level among Colombian students. An investigation conducted by SánchezJabba (2013), from the Banco de la República, found that 90 percent of secondary school students reach a maximum level of A1 - a very basic level - and that only 6.5 percent of students in higher education finish with 
a $\mathrm{B}+$ level, the minimum level to be considered bilingual. The bleak report from 2013 showed that only 2 percent of students leave secondary school with a B1 level of English, the basic level which gives the ability to understand and converse but which is by no means fluent.

This report is cause for concern because it means that something is not working as it should be; there are aspects to be evaluated and modified. From the author's point of view, the government must conduct a thorough analysis at all institutions to pinpoint their necessities and understand the contexts in which the programs are to be implemented. This does not mean that applying the standards of the CEFR is not worthy of consideration, but it could be valuable for Colombian educators and officials to develop their own standards based on the findings of such an analysis.

According to research made in Colombia, several factors have contributed to the problems people now face in bilingual education programs. The main actors in the process are, of course, teachers and students, both of whom have been judged negatively based on the results attained up to now. The results of the report from Banco de la República show that it is not only students who have a low level of English. In fact, the report showed that nearly fifty percent of English teachers in public schools did not have a B1 level of English, the basic level needed to communicate and understand the language (MEN, 2009).

A 2013 report showed a slight improvement, with 25 percent of teachers in public education achieving a level higher than $B$ and 35 percent holding the most basic B1 level. However, 14.4 percent of teachers teaching English to students hold a level of A-, meaning that they have a minimal grasp of the language and would struggle to understand or communicate in spoken or written English. This factor often has to do with the universities these teachers are graduated from and the education they received during their major. Another consideration is, as the author has experienced, that it is not enough to be an excellent English speaker and to have a high level of proficiency, but it is also necessary to be a teacher able to transmit knowledge, a teacher with communicative abilities and who is an active part of the educational community. Only in this way will teachers be able to understand their context in enough depth and employ the best tools to help their students understand and learn via an appropriate approach to the learning process.

Teachers also need to be trained to adapt the standards from the CEFR into their lessons. They are given the syllabus and program and told what level students must attain. According to the author's experience, teachers are not given the chance to learn how to apply these standards in their English classes. 
Teachers need to be updated with new trends and concepts in education. If the government requires qualified teachers, it then needs to provide quality training. This training must be promoted among young teachers with the purpose of building a new generation of educators able to apply new knowledge in their local contexts and overcome the weaknesses of the bilingual program the government has promoted. Students are the main client group and are the reason teachers are working in the first place. It is surprising, then, that over 90 percent of Colombian student population is failing to meet the goals of the National Bilingual Program, which aims to ensure Colombians have at least B1 English. There is a disconnect between theory and reality.

With this National Bilingual Program, students are left with two options: leave school with a very basic level of English which does actually not meet the published exit standards, or enroll in a private language academy. The second option has been gaining popularity as of late, with many students from public and private schools taking supplementary English courses for support in attaining a higher English proficiency level. However, not everyone can pick the second option because these courses are usually not cheap and will undoubtedly be unavailable for many students who are not from wealthy backgrounds. Students should not be faced with choosing one of these options, as the government itself states that students have the right to receive quality education, including the opportunity to attain a B1 level in English. That means the Ministry of National Education must guarantee that this right be afforded to students in all schools, independent of their socio-cultural or socioeconomic circumstances. If students are guaranteed this right, surely they will have a better chance to attain the required English level in their higher education.

Having discussed the National Bilingual Program and bilingualism in our country, and bearing in mind the main topic of this article, the following part focuses on bilingualism in Colombian higher education, for which there is not much information about the incidence of bilingualism. Over recent years, universities have begun facing the challenge of moving from monolingual higher education to bilingual higher education.

\section{Bilingualism at university level.}

Bilingualism in university contexts is as important as in schools. For postsecondary students, learning a second language presents students with wider range of opportunities to improve in different aspects of their lives. The possibility to travel, to experience other cultures, to communicate with different people, and to obtain better job opportunities are among other crucial factors which motivate students who dream of a bright future. There are other facts in favor of participating 
in university bilingual programs. As Lasagabaster (2008) rightly noted, the overall benefits of this type of education are linked to improved motivation, the strengthening of intercultural communicative competence, meaningcentered and communication-centered learning, and improvement of overall target language proficiency.

For the Colombian context, one of the most evident problems is the lack of opportunities to practice English outside the university language class; i.e., students do not have many chances to use what they are learning in the classrooms or tutoring sessions. Other academic departments and even administrative boards not directly related to the Languages Department seem not to consider English as pertinent to their work and usually wash their hands out of it, discharging all the responsibility onto language educators, unaware that for a bilingual program to be successful, all the stakeholders need to contribute. In the aforementioned private university in Sogamoso, particularly, bilingualism is language teachers' responsibility. What students learn and do not learn is often because of their teachers; in order to succeed in this task of producing bilingual graduates, it is necessary to have the commitment of everyone involved in the education process. If students receive support from all the faculties, they are going to see bilingualism as worthy in their lives. As McGroarty (2001) explains, the ideal conditions for bilingual programs to be effective require a sound curricular articulation, acquisition of resources in both languages, availability of qualified staff in both languages, a systematic assessment of the achievements attained, and the participation of the whole academic community: educational directors, administrative staff, teachers and students. Combined, these create the conditions in which a person can become bilingual.

Bostwick (2001), describing a successful program in Japan, mentions teacher certification and recruitment as one of the features contributing to the quality of a program. In the same way, Weber (2001), describing a similar circumstance in Indiana, USA, specifies the need to engage and retain high quality staff in order to maintain effectiveness. Teachers are considered a vital part of the success of bilingual programs, but are they given the right pedagogical tools and assessment mechanisms to do their job in the best way? Teachers are important actors in the process, thus they need to be effectively trained (pre- and in-service) to become high quality teachers.

For example, the situation at the private university is very complex. It is very common that only the professors belonging to the Languages Department know another language. When taking a look at the other departments, it can be observed that most of them are monolingual. They only speak Spanish and the few professors that speak 
English have not been trained to teach their disciplines in a foreign language. According to Granados (2013), a similar situation occurred at Universidad Central in Bogotá, where only teachers from the Languages Department speak more than one language.

In that regard, the directors of the different faculties have thought about the possibility of opening an English course to all the teachers who desire to learn a foreign language. There has been a problem concerning the time schedule, considering the already heavy workload most professors carry, in addition to reservations about the amount of money they have to pay for this course. Offering it for free might motivate teachers to learn and improve their English level.

Cummins (2008) states, there are other ways to foster bilingualism, and one is the implementation of bilingual programs for students at the university. These programs range from what is technically considered as bilingual education, the use of two languages of instruction at some point in a student's school career, to the implementation of specific learning activities in which the target language is used as a tool to develop new learning about a subject area or theme. Indeed, attempts are now being made to develop a more organized structure which seeks to encourage teachers to begin teaching their subjects in the students' shared second language.
However, the implementation of such programs requires more than just the good intentions of the university administrators and faculty involved (Marsh, Pavón and Frigols, 2013). Unfortunately, there are many misconceptions that lead some people to believe that these programs can be implemented simply by changing the language in which the subjects are taught. There are several other aspects involved in order for the program to be effective.

One of the principle aims of implementing content-based bilingual programs which teach academic subjects at universities in another language is to improve students' competence in the second language, thus equipping them with a very useful tool for their professional future. Following Lorenzo et al. (2011), another aim is to promote multilingual competencies that will enable citizens to participate in social processes in international contexts. According to Coleman (2006), there are important reasons that explain why English is being increasingly used as the language of instruction at the university level, namely internationalization, student exchanges, teaching and research materials, staff mobility, graduate employability, and the growing number of foreign students enrolling in university studies.

The implementation of a contentbased bilingual program in a university is not an easy undertaking in part due to the difficulties that students find in 
assimilating complex academic content through a language that they may not have yet mastered. Such students run the risk of not successfully acquiring the same level of content knowledge as would be the case if they were taught in their mother tongue. As noted by Lawrence (2007), the acquisition of productive skills (speaking and writing) may be impaired, and at the same time, the assimilation of the content could also be altered by the mediation of the second language. To this point, the author emphasizes the importance of offering bilingual education from even the very beginning levels of primary school. If children are taught English from early on and are given the necessary tools and strategies to cope with receiving content delivery in English, they certainly will have a significant a scholastic advantage over those who first enroll in bilingual programs as adults.

However, Hellever and Wilkinson (2009) report that recent studies conducted at the University of Maastricht revealed that students engaged in academic programs using an additional language achieve the same or even better academic performance than their peers who study in programs taught in their mother tongue. This finding is really interesting because it shows the impact bilingual education has on overall university level learning.

The most effective way to avoid potential language problems would be to establish an initial level of linguistic competence for students. It can be demonstrated by means of an initial proficiency exam which accurately and objectively measures the student's level of competence in English. Moreover, the university could also offer language preparation courses for those who do not meet the minimum entry level requirement.

A second problem is related to teachers' language proficiency. Teachers may also suffer from stress when realizing that they lack the necessary resources to address a variety of classroom situations. Dafouz and Núñez (2009) explain that university teachers should combine two different types of competences: the first is related to a general language proficiency and competence in the different linguistic skills, and the second to the other genrebased specific competences particular for academic contexts: "...university teachers would need to successfully exploit generic and textual competences at two different levels: a situational and global one and a disciplinary or local one" (Dafouz and Núñez, 2009, p. 108). University teachers need the tools to take advantage of what they know to guide their students and, at the same time, feel free to teach without any interference.

\section{Conclusions}

One way to expand bilingual education is to implement more programs which teach students through 
English, underpinned by the specific needs, objectives and, above all, the characteristics of the particular educational context in which they are implemented. This presents a tall mountain to climb because, as the author has experienced, the linguistic competence of the teachers and students is often insufficient. Implementing a bilingual program which is based on specific and widely tested methodology should start with a clear definition of the objectives to be achieved, taking into account the time needed to achieve them and the particular characteristics of each university. An analysis of the level of competency of both, teachers and students as well as current methodology effectiveness will determine the specific measures to be taken to ensure a successful program. These would likely include training teachers in language and bilingual methodology, coordinating the teaching of academic content and language needs, and improving students' second language competence. To achieve the desired results, it is important that bilingual programs involve dedicated teachers and interested students, and they need to be supported by university administrators and program leaders that understand the management and pedagogical principles involved. McGroarty (2001) states the need for concerted efforts among teachers, institutions, students and families for successful bilingual programs, while Baker (2011) talks about a shared vision, mission and goals among staff as well as the leadership of the institution as begin critical factors for success.

If those in charge want the programs aimed at promoting English in the different institutions to amount to more than "good paper intentions" (Shohamy, 2006, p.143), it is necessary to act in a serious way. Colombia requires a reform process in which all the educational actors are involved and which checks all the levels. Significant responsibility falls on the people who are in charge of bilingual program management and those in charge of English teaching.

Bilingual education in our country, as has been illustrated throughout this article, has many difficulties that impede its ability to achieve the best possible outcomes. Accordingly, higher education institutions should develop strategies and plans that let teachers continuously improve their second language teaching effectiveness and that let students improve their second language competence based on the levels they have upon entering the university. Another challenge involves changing the importance learning English has for university students. For the most part, it is seen as simply as an additional graduation requirement rather than a valuable asset for their future.

It is vital to monitor the creation and implementation of bilingual programs in higher education since they are often focused more on generating income 
than on supplying students with real second language competencies. There is also a tendency to demand that students in higher education become bilingual within four or five years, not taking into account that they often do not have even a basic English level upon entry. The universities are charged with producing bilingual Colombians, but many students lack the linguistic foundation to achieve that goal. Therefore, it is necessary that the national government demonstrate a clearer and more rigorous focus on the implementation of English as a foreign language instruction throughout their schooling, starting in the earliest grades.

\section{References}

Ayala, J., \& Álvarez, J. (2005). A perspective of the implications of the Common European Framework implementation in the Colombian socio-cultural context. Colombian Journal of Applied Linguistics 7, 7-26.

Baker C., (2011). Foundations of Bilingual Education and Bilingualism. 5th ed. Clevedon: Multilingual Matter. (Versión en español: Baker C., (1993). Fundamentos de Educación Bilingüe y Bilingüismo. Madrid: Cátedra).

Bloomfield, L. (1933). Language. New York: Holt.

Bostwick, M. (2001). English immersion in a Japanese school. In D. Christian \& F. Genesee (Eds.), Bilingual education. Alexandria, VA: TESOL pp. 125-137.
Brown, R. (1973). A first language: The early stages. Cambridge MA: Harvard University Press.

Cárdenas, M. (2006). Bilingual Colombia: Are we ready for it? What is needed? Paper presented at the $19^{\text {th }}$ Annual English Australia Education Conference. Perth, Western Australia, 14-16 September, 2006.

Cárdenas, R., Chaves, O. \& Hernández, F. (2015). Implementación del Programa Nacional de Bilingüismo en Cali, Colombia: Perfiles de los docentes de inglés. Cali, Colombia: Universidad del Valle.

Cely, R. M. (2007). Una Colombia bilingüe. Entrevista con Rosa María Cely. Eleducador.com. Retrieved May 08, 2008 from http:// www.eleducador. com/col/contenido/contenido.aspx? catID=107\&conID=205.

Coleman, J. (2006). English-medium teaching in European higher education. Language Teaching (39), 1-14.

Council of Europe (2001). Common European Framework of Reference for Languages: Learning, Teaching, and Assessment. Cambridge University Press, Cambridge.

Coyle, D., Holmes, B., \& King, L. (2009). Towards an integrated Curriculum: CLIL National Statements and Guidelines. The Languages Company. London.

Cummins, J. (2008), Introduction to Volume 5: Bilingual Education, in J. Cummins and N. Hornberger (eds.), Encyclopedia of Language and Education, Volume 5: Bilingual Education, (xii-xxiii). Springer 
Science and Business Media LLC, New York.

Dafouz, E. \& Núñez, B. (2009). CLIL in higher education: devising a new learning landscape, in E. Dafouz and M. Guerrini (eds.), CLIL Across Educational Levels: Experiences from Primary, Secondary and Tertiary Contexts (101-112). Madrid: Santillana-Richmond.

De Mejía, A.-M. (2011). The national bilingualism program in Colombia: Imposition or opportunity? Apples, Journal of Applied Language Studies, 5 (3), 7-17

Erlbaum. L. (2007). Understanding Language Teaching. From Method to Postmethod, Nueva Jersey

Giroux, H. (1988). Teachers as intellectuals. Massachusetts: Bergin and Garving Publishers.

González, A. (2007). Professional development of EFL teachers in Colombia: Between colonial and local practices. Íkala, Revista de Lenguaje y Cultura, 12 (18), 309-332.

González, A. (2015). Tomorrow's EFL teacher educators. Colombian Applied Linguistics Journal, 5, 86-104. Recuperado de http://revistas.udistrital.edu.co/ ojs/index.php/calj/article/view/183

Granados, C. (2013). Challenges of Bilingualism in Higher Education: The Experience of the Languages Department at the Universidad Central in Bogotá, Colombia. Gist Education and Learning Research, 7, 245-258.

Grosjean, F. (1982). Life with Two Languages: An Introduction to Bilingualism.
Cambridge, Mass: Harvard University Press, p. 370.

Guerrero, C. H., \& Quintero, A. (2005). Teachers as mediators in undergraduate students' literacy practices: Two pedagogical experiences. How Journal, 11, 45-54.

Hellever, G., \& Wilkinson, R. (2009). CLIL in higher education, Euro CLIL, Bulletin (7). Retrieved from the net: http:// www.euroclic.net/index.php?inhoud/ bulletin/bulletin7/8.htm

Hulstijn, J. H. (2010). Measuring second language proficiency. In E. Blom \& S. Unsworth (eds.), Experimental methods in language acquisition research (EMLAR), Amsterdam: John Benjamins.

Lasagabaster, D. (2008). Foreign language competence in content and language integrated courses, The Open Applied Linguistics Journal 1, 30-41.

Lorenzo, F., Trujillo, F. and Vez, J.M. (2011). Educación Bilingüe: Integración de Contenidos y Segundas Lenguas. Síntesis, Madrid.

Marsh, D., Pavón, V. \& Frigols, M. (2013). The Higher Education English Language Landscape: Ensuring Quality in English Language Degree Programmes. Valencia International University, Valencia.

Mc Groarty, M. (2001). Bilingual approaches to language learning. In $M$. CelceMurcia, D. M. Brinton \& M. A. Snow (Eds.). Teaching English as a second or foreign language (3rd Ed.) (p. 345-353). Boston, MA: Heinle \& Heinle.

Mejía, A. M. (2004). Bilingual Education in Colombia: Towards an Integrated 
Perspective. Bilingual Education and Bilingualism, 7(4), 381- 397.

MEN (2009). II encuentro de instituciones de Educación Superior, Fortalecimiento del desarrollo de competencias en lengua extranjera Programa Nacional de Bilingüismo.

Ministerio de Educación Nacional. (2005). Al Tablero. No. 37. October December. Retrieved from: http:// www.mineducacion.gov. co/1621/ article-97495.html.

Pennycook, A. (1998). English and the discourses of colonialism. New York, NY: Routledge.

Ruiseco, G., \& Slunecko, T. (2006). The role of mythical European heritage in the construction of Colombian national identity. Journal of Language and Polotics, 5(3), 359-384.

Shohamy, E. (2006). Language policy: Hidden agendas and new approaches. New York, NY: Routledge.

Skutnabb-Kangas, T. (1981): Bilingualism or no: The education of minorities, Clevedon, Multilingual Matters.

Skutnabb-Kangas, T. (1984). Bilingualism or not the education of minorities. Clevedon, Avon: Multilingual Matters. p. 378

Snow, C. E. (2007). Determinants of the Outcomes of Language Education: Developmental and Sociolinguistic Factors. In Memorias del Segundo Simposio Latinoamericano de Bilingüismo y Educación Bilingüe en América Latina. Bogotá: Ediciones Uniandes. (p. 2-12).

Usma, W. (2004). Evaluating research skills development in a Colombian Undergraduate Foreign Language
Teaching Program." Ikala, Language and Culture Journal, 10(16), 95 - 125.

Usma, J. (2009). Globalization and language and education reform in Colombia: A critical outlook. Íkala, Revista de Lenguaje y Cultura, 14 (22), 19-42.

Valencia, G. S. (2005). Bilingualism and English language teaching in Colombia: A Critical outlook. Paper presented at the Conference on English Language Teaching in Colombia, October, Universidad del Quindío.

Vargas, A., Tejada, H., and Colmenares, S. (2008). Estándares básicos de competencias en lenguas extranjeras (inglés): una mirada crítica. Lenguaje, 36(1), 241-275.

Weber, A. (2001). An international bilingual school in Indiana, USA. In D. Christian \& F. Genesee (Eds.), Bilingual education (p. 151-165). Alexandria, VA: TESOL. 